\title{
GERMINATION RATE OF PENNISETUM GLAUCUM SEEDLING IN FUCTION OF SALINE STRESS, GROWTH AND BIOMASS OF AERIAL PART AND ROOT
}

\author{
Leandro Ricardo Rodrigues de LUCENA ${ }^{1}$ \\ Vicente José Laamon Pinto SIMÕES ${ }^{1}$ \\ Cinara Wanderléa Felix BEZERRA ${ }^{1}$ \\ José Lypson Pinto Simões IZIDRO ${ }^{1}$ \\ Marcondes Sá SOUZA ${ }^{1}$ \\ Maurício Luiz de Mello Vieira LEITE ${ }^{1}$
}

- ABSTRACT: Millet is an annual cycle plant, with C4 metabolism, tolerant to water deficit, and it is cultivated in regions with scarcity of rain. The objective was to evaluate the germination of the millet seedling in function of saline stress, growth and biomass of the aerial part and the root system. The experiment was performed in a completely randomized design, with four treatments and five replicates, with the unit being represented by seeds of millet. The treatments were constituted by solutions with addition of $\mathrm{NaCl}$ corresponding to $2.337,4.674$ and $7.011 \mathrm{~g} / \mathrm{L}$, respectively for the electrical conductivities $4.0 ; 8.0 ; 12.0 \mathrm{dS} / \mathrm{m}$ and $0 \mathrm{dS} / \mathrm{m}$ (distilled water) as control. The millet cultivar used in this experiment was the IPA Bulk 1BF. The mean germination rate of seedlings in relation to control salinity level was higher than $90 \%$, while for level of $12 \mathrm{dS} . \mathrm{m}^{-1}$ salinity there was no germination. The fitted model presented a high coefficient of determination of model (pseudo- $\mathrm{R}^{2}=90.96 \%$ ) and low sum of squares of residuals $(\mathrm{SSR}=0.26)$. The beta regression model proved to be an appropriate option to analyse the millet seedling germination rate after 72 hours in function of salinity level, length of the root system and dry mass of the aerial part.

- KEYWORDS: Beta regression, millet, modelling, mortality

\section{Introduction}

Millet (Pennisetum glaucum) is an annual cycle plant, with C4 metabolism, and tolerant to water deficit (ULLAH et al., 2017; SINGH et al., 2015). It is cultivated in places with scarcity of rain, which is an important fact due to its low water demand (DAN et al., 2010). This plant is used as an alternative for grain production and pasture grown in semi-arid regions, due to the high production of biomass and nutritive value (SANTOS et al., 2017; GHATAK et al., 2016). Regarding salinity, millet presents moderate tolerance,

\footnotetext{
${ }^{1}$ Universidade Federal Rural de Pernambuco - UFRPE, Campus Serra Talhada, Av. Gregório Ferraz Nogueira, CEP: 56909-535, Serra Talhada, PE, Brasil. E-mail: leandroricardo_est@yahoo.com.br; laamoneng.agro@gmail.com; rinara_wanderlea@outlook.com; $\quad$ lypsonsi.zootec@gmail.com; marcondes.sa33@gmail.com; nopalea21@yahoo.com.br
} 
with more than $70 \%$ reductions in seed germination and seedling growth when it is submitted to the concentration of $250 \mathrm{mM}$ of $\mathrm{NaCl}$ (KRISHNAMURTHY et al., 2007).

The morphometric measurements of millet, such as the length of the aerial part and of the root system, are associated characteristics that directly influence the production of phytomass (LEITE et al., 2017). These characteristics are positively correlated with the productivity of forage plants (LEITE et al., 2017). However, several stages of millet development are affected by the salinity of irrigation water, which directly influences the productivity of this plant (HUSSAIN et al., 2010).

High concentrations of soluble salts in the soil solution, mainly $\mathrm{NaCl}$, and other ions, such as $\mathrm{Mg}^{2+}, \mathrm{HCO}^{3-}$ and $\mathrm{SO}_{4}{ }^{2-}$, cause inhibition of plant growth, due to the decrease in the water potential of the soil solution at a level below the necessary for the absorption of water (SOARES et al., 2015). There are few studies on the effect of salinity in millet culture in the literature, and, in addition, it has been verified that the increase of salts in the soil due to use of low quality water for irrigation causes many adverse consequences in the morphology, anatomy and physiology of this culture (HUSSAIN et al., 2010). According to Hussain et al. (2008), the percentage of germination, height, grain and yield of millet straw decrease as salinity increases.

However, it must be considered that the groundwater of most of the planet's semiarid regions has a high concentration of salts (SILVA et al., 2017). Thus, the use of species that are more resilient to environmental modifications is necessary in order to increase agricultural productivity. In view of this context, the objective was to evaluate the germination of the millet in function of saline stress, growth and biomass of the aerial part and the root system.

\section{Material and methods}

The research was carried in the Universidade Federal do Pernambuco, Academic Unit of Serra Talhada (UFRPE/UAST), Serra Talhada city, Pernambuco state, Brazil (elevation: $429 \mathrm{~m}$, latitude: $7^{\circ} 56^{\prime} 15^{\prime \prime} \mathrm{S}$ and longitude: $38^{\circ} 18^{\prime} 45^{\prime \prime} \mathrm{E}$ ). According to Koppen, the climate condition is a BSwh', which is denominated Semiarid, hot and dry, with rainy season during the summer, with average annual rainfall of $647 \mathrm{~mm} / \mathrm{year}$ and average air temperatures greater than $25^{\circ} \mathrm{C}$ (LEITE et al., 2017).

The experiment was performed in a completely randomized design, with four treatments and five replicates, and the experimental unit was represented by a tray of 120 cells containing 24 seeds per treatment (Figure 1). The treatments were constituted by solutions with addition of $\mathrm{NaCl}$ corresponding to $2.337,4.674$ and $7.011 \mathrm{~g} / \mathrm{L}$, respectively for the electrical conductivities of (EC) $4.0 ; 8.0 ; 12.0 \mathrm{dS} / \mathrm{m}$, and $0 \mathrm{dS} / \mathrm{m}$ (distilled water) as control.

The millet cultivar (Pennisetum glaucum) used in this experiment was the IPA Bulk 1BF. The seeding occurred on May 30, 2018, in styrofoam trays $(67.4 \times 34 \times 6.1 \mathrm{~cm})$, which had sand and vermiculite as the substrate in a 1:1 ratio. Initially, the substrate was humidified to field capacity, with water from each saline level evaluated and conducted in greenhouse. During the conduction of the experiment, the irrigations were carried once a day, in order to keep the humidity close to the field capacity, in order to leave the substrate in saturated conditions. 


\begin{tabular}{|l|l|l|l|l|l|l|l|l|l|}
\hline 1 & 2 & 1 & 2 & 1 & 2 & 1 & 2 & 1 & 2 \\
\hline 3 & 4 & 3 & 4 & 3 & 4 & 3 & 4 & 3 & 4 \\
\hline 5 & 6 & 5 & 6 & 5 & 6 & 5 & 6 & 5 & 6 \\
\hline 1 & 2 & 1 & 2 & 1 & 2 & 1 & 2 & 1 & 2 \\
\hline 3 & 4 & 3 & 4 & 3 & 4 & 3 & 4 & 3 & 4 \\
\hline 5 & 6 & 5 & 6 & 5 & 6 & 5 & 6 & 5 & 6 \\
\hline 1 & 2 & 1 & 2 & 1 & 2 & 1 & 2 & 1 & 2 \\
\hline 3 & 4 & 3 & 4 & 3 & 4 & 3 & 4 & 3 & 4 \\
\hline 5 & 6 & 5 & 6 & 5 & 6 & 5 & 6 & 5 & 6 \\
\hline 1 & 2 & 1 & 2 & 1 & 2 & 1 & 2 & 1 & 2 \\
\hline 3 & 4 & 3 & 4 & 3 & 4 & 3 & 4 & 3 & 4 \\
\hline 5 & 6 & 5 & 6 & 5 & 6 & 5 & 6 & 5 & 6 \\
\hline
\end{tabular}

Figure 1 - Experimental design (blue - control treatment; red - treatment with $8 \mathrm{dS} / \mathrm{m}$; gray treatment with $4 \mathrm{dS} / \mathrm{m}$ and yellow - treatment with $12 \mathrm{dS} / \mathrm{m}$ ).

To evaluate the effect of salt stress, we collected information of the length from the aerial part (LAP) and root (RSL), dry mass of the aerial part (DMAP) and of the root (DMRS). The results of these measures were compared by the Kruskal-Wallis test. The lengths were measured with the aid of millimetre ruler and expressed in centimetres. The aerial part was measured from the base of colon to the apex of the apical meristem of the seedling, and the root length was obtained from the measurement of the base of colon to the root end of the seedling. At the end of the experiment, we evaluated the germination rate of millet by counting the number of live seedlings divided by the number of seedlings seeded in each replicate. To determine the fresh mass of shoot and root, the collected material was weighed in precision balance $(0.0001 \mathrm{~g})$. To determine the dry mass, the parts of the plants were conditioned in paper bags and set to dry in drying oven with forced air circulation at $65^{\circ} \mathrm{C}$, during 72 hours. After this period, the samples were weighed, and the results were expressed in $\mathrm{g} /$ seedling.

Regression analysis is a statistical technique used to model, based on a set of information, the relationship between the variable of interest and one or more explanatory variables. For situations where the response is continuous and restricted to the interval $(0$, 1), such as rates and proportions, Ferrari and Cribari-Neto (2004) have proposed the beta regression model.

The beta regression models are being used to evaluate the percentage of shrub cover (EKLESTON et al., 2011) and to model the diameter and height of trees (LI et al., 2002). Ferrari and Cribari-Neto (2004) proposed the beta regression model class, in which the response variable (Y) has a beta distribution.

Let $\mathrm{Y}$ be a random variable with Beta distribution $(\mathrm{p}, \mathrm{q})$, then define its probability density function by:

$$
f(y ; p, q)=\frac{\Gamma(p+q)}{\Gamma(p) \Gamma(q)} y^{p-1}(1-y)^{q-1}
$$

where, $y$ is the continuous variable in the interval $(0,1), p>0$ and $q>0$ are parameters of the probability density function and $\Gamma\left(^{*}\right)$ is the gamma function, which is defined by: 


$$
\Gamma(\mathrm{p})=\int_{0}^{\infty} \mathrm{y}^{\mathrm{p}-1} \mathrm{e}^{-\mathrm{y}} \mathrm{dy}
$$

Ferrari and Cribari-Neto (2004) proposed a different parameterization of the beta probability density function, by setting $\mu=\mathrm{p} /(\mathrm{p}+\mathrm{q})$ and $\emptyset=\mathrm{p}+\mathrm{q}$, this is, $\mathrm{p}=\mu \emptyset$ and $\mathrm{q}=(1-$ $\mu$ ) $\varnothing$, so the density function is expressed by:

$$
\mathrm{f}(\mathrm{y} ; \mu, \emptyset)=\frac{\Gamma(\varnothing)}{\Gamma(\mu \emptyset) \Gamma((1-\mu) \emptyset)} \mathrm{y}^{\mu \emptyset-1}(1-\mathrm{y})^{(1-\mu) \emptyset-1}
$$

where, $\mu(0<\mu<1)$ is the parameter associated with the mean of the response variable and $\emptyset>0$ is the precision parameter. Its mean and variance are defined by, $E(Y)=\mu$ and $\operatorname{Var}(\mathrm{Y})=\frac{\mu(1-\mu)}{1+\varnothing}$.

Let $\mathrm{y}=\left(\mathrm{y}_{1}, \mathrm{y}_{2}, \ldots, \mathrm{y}_{\mathrm{n}}\right)$ be a vector of independent random variables, where each $\mathrm{y}_{\mathrm{i}}(i=1,2, \ldots, n)$ follows the density function Beta, this is, $\mathrm{y}_{\mathrm{i}} \sim B\left(\mu_{\mathrm{i}}, \emptyset_{\mathrm{i}}\right)$, such that the Beta regression model is defined by $\mathrm{f}(\mathrm{y} ; \mu, \emptyset)$.

Then, the structure of the regression model is given by:

$$
\mathrm{g}\left(\mu_{\mathrm{i}}\right)=\eta_{\mathrm{i}}=\beta_{0}+\beta_{1} \mathrm{X}_{\mathrm{i} 1}+\beta_{2} \mathrm{X}_{\mathrm{i} 2}+\cdots+\beta_{\mathrm{k}} \mathrm{X}_{\mathrm{ik}}
$$

where, $\eta$ is the linear predictor, $\beta=\left(\beta_{0}, \beta_{1}, \beta_{2}, \ldots, \beta_{\mathrm{k}}\right)$ is the unknown parameter vector and $\mathrm{X}_{\mathrm{i} 1}, \mathrm{X}_{\mathrm{i} 2}, \ldots, \mathrm{X}_{\mathrm{ik}}$ are the observations of $\mathrm{k}$ independent variables known $(\mathrm{k}<\mathrm{n})$ and $\mathrm{i}=1,2, \ldots, \mathrm{n}$. In the beta regression model, you can choose different link functions, such as the logit function:

$$
g(\mu)=\log \left(\frac{\mu}{1-\mu}\right)
$$

where, the average of variable $\mathrm{y}_{\mathrm{i}}$ can be written according to the explanatory variables by the following expression:

$$
\mu_{i}=\frac{\exp ^{\left(\beta_{0}+\beta_{1} X_{i 1}+\beta_{2} X_{i 2}+\cdots+\beta_{k} X_{i k}\right)}}{1+\exp ^{\left(\beta_{0}+\beta_{1} X_{i 1}+\beta_{2} X_{i 2}+\cdots+\beta_{k} X_{i k}\right)}}
$$

where, $0<\mu_{\mathrm{i}}<1$. The estimation of the coefficients is obtained by maximizing the loglikelihood function, and the adjustments are evaluated by the pseudo coefficient of determination of the model (pseudo- $\mathrm{R}^{2}$ ), by the square sum of residuals (SSR), Akaike information criteria (AIC) (AKAIKE, 1974) and Bayesian information criteria (BIC) (SCHWARZ, 1978). The contribution of each variable will be defined by $\exp ^{\left(\beta_{\mathrm{i}}\right)}$ (FERRARI and CRIBARI-NETO, 2004).

In this study, the response variable is defined as germination rate (GR) of millet seedlings, and the explanatory variables are refined by: salinity levels (SAL), length of the aerial part and root system, as well as the dry mass of aerial part and root system. The Beta regression model was initially proposed by: 


$$
G R=\frac{\exp ^{\left(\beta_{0}+\beta_{1} S A L+\beta_{2} L A P+\beta_{2} R S L+\beta_{3} D M A P+\beta_{4} D M R S\right)}}{1+\exp ^{\left(\beta_{0}+\beta_{1} S A L+\beta_{2} L A P+\beta_{2} R S L+\beta_{3} D M A P+\beta_{4} D M R S\right)}}
$$

where, the contribution of the variables salinity level in the germination rate is defined by $\exp ^{\left(\beta_{1}\right)}$; the contribution of aerial part length is expressed by $\exp ^{\left(\boldsymbol{\beta}_{2}\right)}$; of root system length by $\boldsymbol{e x p}^{\left(\beta_{3}\right)}$; dry mass of aerial part by $\exp ^{\left(\beta_{4}\right)}$ and dry mass of root system by $\boldsymbol{e x p}^{\left(\boldsymbol{\beta}_{5}\right)}$. All analyses were made by the R software (R CORE TEAM, 2018) with the aid of the betareg package (CRIBARI-NETO and ZEILEIS, 2010).

\section{Results and discussion}

The mean germination rate of seedlings from the control salinity level was higher than $90 \%$. For the level of $4 \mathrm{dS} / \mathrm{m}$, the germination rate was around $67.5 \%$, while at the level of $8 \mathrm{dS} / \mathrm{m}$, the germination rate was less than $50 \%$. Nonetheless, for the maximum level of salinity, the germination rate of seedlings was $0 \%$. The Kruskal-Wallis test shows that the germination rate decreases with the increase of the salinity level (pvalue $<0.0001$ ), Figure 2.

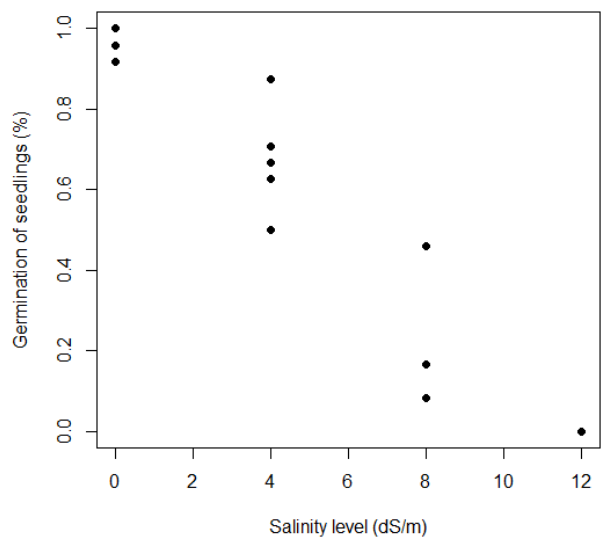

Figure 2 - Germination rate of millet seedlings in function of salinity level.

In a study aiming to identify millet strains [Pennisetum glaucum (L.) R. Br.] tolerant to salinity, Krishnamurthy et al. (2007) found divergent results, where at a salinity of approximately $25 \mathrm{dS} / \mathrm{m}$, there was a $70 \%$ reduction of germination and seedling growth, whereas in the present study, the salinity of $12 \mathrm{dS} / \mathrm{m}$ was sufficient to cause total mortality 
of seedlings. Thus, it is suggested that the cultivar used in our research may have a lower tolerance to salinity when compared to other millet cultivars. However, this tolerance can be classified as moderate, since at the level of $4 \mathrm{dS} / \mathrm{m}$, the plants had a reduction of $22.5 \%$ in the germination rate, when compared to the control plants.

When evaluating two millet strains, one of which was considered tolerant and another sensitive to saline stress, Hussain et al. (2008) observed that the differentiated growth between these two strains may have been due to differences in transfer rates and accumulation of ions in the aerial part of plants. For the tolerant lineage, the authors showed the lowest transfer rates of $\mathrm{Na}^{+}$and $\mathrm{Cl}^{-}$under the saline stress, due to a better control of the absorption of these ions by the root system, as well as a greater retention of salt in roots. These same authors showed that the excess of $\mathrm{Na}^{+}$and $\mathrm{Cl}^{-}$cause disturbances in relation to ionic balance, which reduces the transfer of ions $\mathrm{K}^{+}$and $\mathrm{Ca}^{2+}$ in relation $\mathrm{Na}^{+}$. The highest content of ions $\mathrm{Na}^{+}$and $\mathrm{Cl}^{-}$were found, by order, in stems, scabs, roots and leaves. This retention of potentially toxic ions in the stem and hem is considered as an example of a mechanism of tolerance of millet to salinity. This suggests that this species exports little $\mathrm{Na}^{+}$from the roots to leaf limbs, thus avoiding the excess of potentially toxic ions in photosynthetic tissues.

These answers evidenced the idea of a selective barrier between the roots and the aerial part, beyond the capacity in compartmentalize these ions in different tissues and cells, which is considered a quite common mechanism of tolerance to salinity in the majority of the glycophytes. According to Araújo et al. (2016), salinity affects plant growth at all stages of development, however, the germination, emergence and initial growth are the most affected phases, in most agricultural crops.

Table 1 reveals that, on average, the greatest length of seedlings, both in the aerial part and root system, were higher for the level of salinity control, with means of 5.6 \pm 0.52 $\mathrm{cm}$ and $7.00 \pm 0.23 \mathrm{~cm}$, respectively. As observed by the Kruskal-Wallis test, the higher salinity level, the lower is the mean length of seedlings, both of the aerial part and root system, with p-value $=0.0018$ and 0.0009 , respectively.

Table 1 - Descriptive measurements of length aerial part (LAP), of root system (RSL), dry mass of the aerial part (DMAP) and of root (DMRS), in function of salinity levels

\begin{tabular}{lccccc}
\hline & \multicolumn{5}{c}{$\begin{array}{c}\text { Salinity levels }(\mathrm{dS} / \mathrm{m}) \\
(\text { Mean } \pm \text { SD) }\end{array}$} \\
& 0 & 4 & 8 & 12 & p-value \\
\hline LAP (cm) & $5.60 \pm 0.52$ & $5.50 \pm 0.36$ & $4.16 \pm 0.77$ & $0.00 \pm 0.00$ & 0.0018 \\
RSL (cm) & $7.00 \pm 0.23$ & $5.82 \pm 0.70$ & $5.78 \pm 0.55$ & $0.00 \pm 0.00$ & 0.0009 \\
DMAP (g/ seedling) & $0.011 \pm 0.004$ & $0.010 \pm 0.005$ & $0.005 \pm 0.001$ & $0.00 \pm 0.00$ & 0.0011 \\
DMRS (g/ seedling) & $0.012 \pm 0.003$ & $0.009 \pm 0.003$ & $0.007 \pm 0.003$ & $0.00 \pm 0.00$ & 0.0018 \\
\hline
\end{tabular}

SD-Standard deviation

In glycophytes, such as pearl millet, the tolerance to salinity is strongly linked to the plant's ability to avoid the accumulation of toxic ions such as $\mathrm{Na}^{+}$and $\mathrm{Cl}^{-}$in aerial part. Conversely, sensitive species cannot avoid this accumulation or perform a compartmentalization of these ions in a specific tissue, and they interfere in cellular metabolism, which will impair the growth (HUSSAIN et al., 2010). This fact was verified 
in our research, where the lengths of aerial part and root system, as well as the dry mass of aerial part and root system were reduced with the increment of more than $4 \mathrm{dS} / \mathrm{m}$ of salinity.

The length of aerial part is a characteristic correlated with the productivity of phytomass, therefore, it is an important variable to be evaluated. The effect of salinity on plant height is related to reduction of soil water potential, which limits the absorption of water by roots, that interfere directly in processes of stretching, cell division and, consequently, in growth of plants (ALVES et al., 2011).

In relation to the dry mass of aerial part and root system, it was verified that the highest means were from the level of salinity control, with values of $0.0111 \pm 0.0035$ $\mathrm{g} / \mathrm{seedling}$ and $0.0122 \pm 0.0027 \mathrm{~g} / \mathrm{seedling}$, respectively (Table 1). As observed by the Kruskal-Wallis test, the mean dry mass of aerial part and root system decreased with the increase of level of salinity, with p-value $=0.0011$ and 0.0018 , respectively. Aquino et al. (2007) also found that the dry root masses were affected when submitted solutions of up to $8 \mathrm{dS} \cdot \mathrm{m}^{-1}$.

The reduction of leaf area, with consequent decrease in the volume of cells, contributes to the osmotic adjustment, when it is assumed that the amount of solute absorbed is concentrated in a smaller volume of cellular juice. However, this reduction also represents changes in partition of photoassimilates, and a decrease in the area destined to the photosynthetic process, which may be related to reduction of dry mass production (ARAÚJO et al., 2010; GOMES et al., 2011).

After estimation of parameters, we verified that the variables length of aerial part, dry mass of the root system and the intercept were not significant, at the level of 5\%, to explain the germination rate of millet seedlings (Table 2). The fitted model initially presented pseudo- $\mathrm{R}^{2}$ of $83.94 \%$, SSR of 0.478 , AIC of -160.46 and BIC -154.49.

Table 2 - Estimation of initial model parameters to explain the germination of Pennisetum

\begin{tabular}{|c|c|c|c|c|}
\hline \multirow[b]{2}{*}{ Variables } & \multicolumn{4}{|c|}{ Adjusting of regression model } \\
\hline & Estimate & Standard deviation & Test statistic & p-value \\
\hline Intercept & 1.437 & 1.455 & 0.988 & 0.323 \\
\hline SAL & -0.508 & 0.115 & -4.429 & $<0.0001$ \\
\hline LAP & -0.352 & 0.302 & -1.167 & 0.243 \\
\hline RSL & 0.656 & 0.288 & 2.276 & 0.023 \\
\hline DMAP & 186.19 & 80.51 & 2.313 & 0.021 \\
\hline DMRS & -267.686 & 132.32 & -1.935 & 0.053 \\
\hline$\varnothing$ & 8.624 & 3.162 & 2.727 & 0.006 \\
\hline
\end{tabular}

In order to find the model that best explains the germination rate of seedlings, new estimates of the parameters were performed. Thus, it was defined that the model that best explains germination rate has the level of salinity, the length of root system and the dry mass of aerial part as the explanatory variables, as showed in Table 3. 
Table 3 - Estimation of the final model parameters to explain seedling germination of Pennisetum glaucum

\begin{tabular}{lcccc}
\hline \multirow{2}{*}{ Variables } & Estimate & \multicolumn{3}{c}{ Adjusting of regression model } \\
\hline SAL & -0.386 & 0.043 & -8.895 & $<$-value \\
RSL & 0.210 & 0.097 & 2.169 & 0.0001 \\
DMAP & 126.86 & 59.016 & 2.150 & 0.0316 \\
$\varnothing$ & 8.022 & 2.958 & 2.712 & 0.007 \\
\hline
\end{tabular}

After estimating the parameters, the fitted model was defined by the following expression:

$$
G R=\frac{\exp ^{(-0.386 S A L+0.21 R S L+126.86 D M A P)}}{1+\exp (-0,386 S A L+0,21 R S L+126,86 D M A P)}
$$

The fitted model presented a high coefficient of determination of model (pseudo- $\mathrm{R}^{2}=$ $90.96 \%$ ), low sum of squares of residuals ( $\mathrm{SSR}=0.26$ ), Akaike information criteria (AIC $=-$ 162.9) and Bayesian information criteria (BIC=-158.92), and such measures qualify the model as appropriate. Through the fitted model, we noticed that with each increment of salinity level, there is a decrease of $32 \%$ in the germination of seedling. Furthermore, at each increment of one centimeter in the length of root system, it is expected a mean increase of $23.37 \%$ in the germination of millet seedling, whereas with an increase of 0.01 grams per seedling in the aerial part dry mass, a mean increase of $26.87 \%$ in the germination of seedling is expected.

Figure 3 shows the observed values of the germination rate of the millet seedlings and those fitted by the model in function of each significant variable. For all the graphs, the values estimated by the model are very close to the observed values, which ensure a good quality of fit of the model.
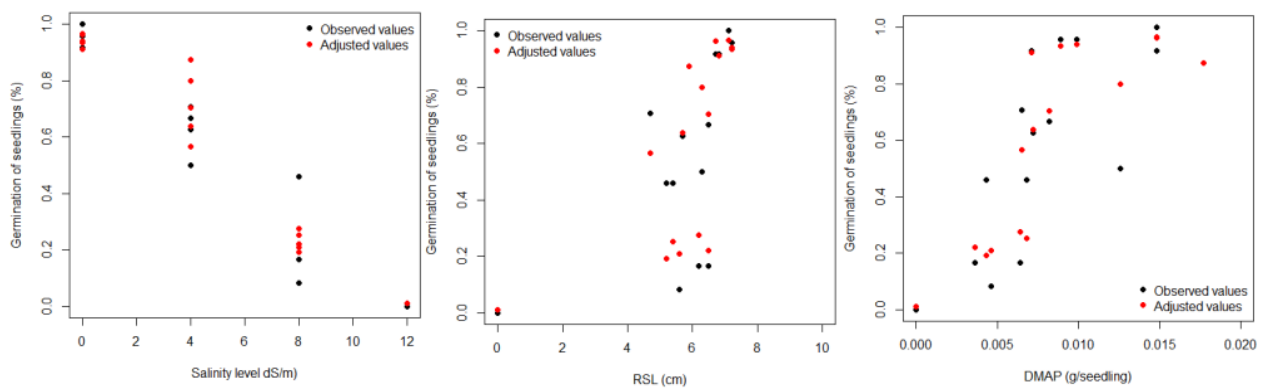

Figure 3 - Relation between the values observed and estimated by the model of germination rate of the millet seedlings in function of the variables: salinity level, root system length and dry mass of aerial part. 
The Figure 4 shows different millet seedling germination scenario by setting a root system length of $5 \mathrm{~cm}$, variable salinity level, from 0 to $15 \mathrm{dS} / \mathrm{m}$, as well as the aerial dry mass, of 0.005 to $0.015 \mathrm{~g} / \mathrm{seedling}$. We verified that the highest germination rate for all saline levels is given for scenarios whose RSL is $5 \mathrm{~cm}$ and the dry mass of aerial part is $0.015 \mathrm{~g} /$ seedling, while the smaller values are given for scenarios with RSL of $5 \mathrm{~cm}$ and aerial part dry mass of $0.005 \mathrm{~g} / \mathrm{seedling}$. According to Nobre et al. (2013), the most sensitive organ of plants, regarding the effects of salts, in general, are the leaves. According to Cavalcante et al. (2010), the excess of potentially toxic ions such as $\mathrm{Na}^{+}$and $\mathrm{Cl}^{-}$promote various physiological disturbances to the plant, which can cause their death. These results reinforce the hypothesis that, the tolerance to salt stress in initial development of millet seedlings, and its germination, is directly related to the capacity to avoid transfer and accumulation of ions $\mathrm{Na}^{+}$and $\mathrm{Cl}^{-}$in the plant's aerial part.

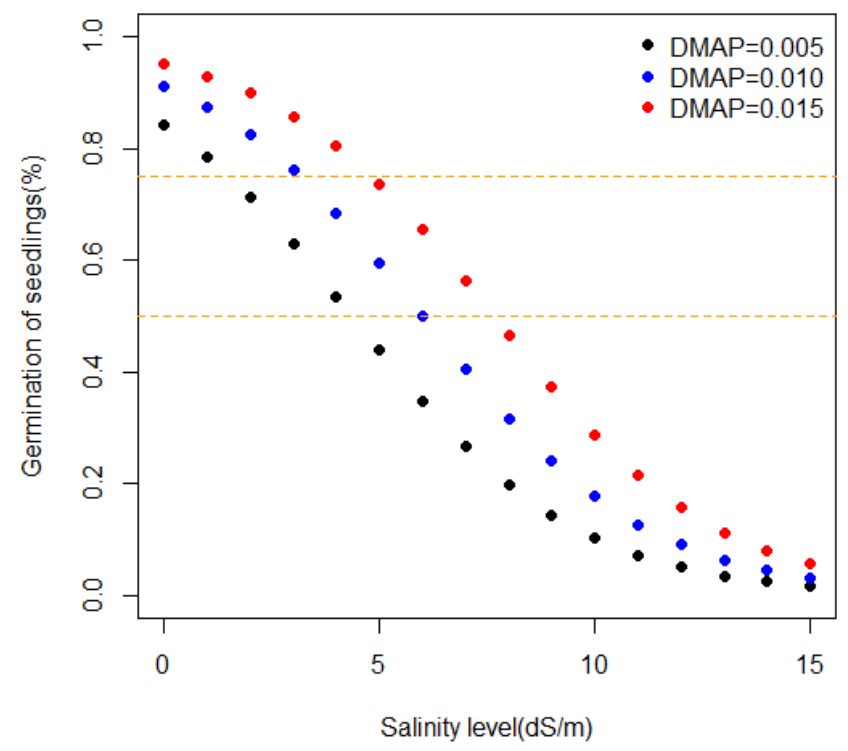

Figure 4 - Germination of millet seedlings for a $5 \mathrm{~cm}$ root system, with different levels of salinity and dry mass of aerial part.

As observed in Figure 4, 50\% of the seedlings germination with a salinity degree of $4.36 \mathrm{dS} / \mathrm{m}$ for RSL of $5 \mathrm{~cm}$ and DMAP of $0.005 \mathrm{~g} / \mathrm{seedling}$. This same rate is obtained with $6 \mathrm{dS} / \mathrm{m}$ for RSL of $5 \mathrm{~cm}$ and DMAP of $0.010 \mathrm{~g} / \mathrm{seedling}$, and with $7.65 \mathrm{dS} / \mathrm{m}$ for RSL of $5 \mathrm{~cm}$ and DMAP of $0.015 \mathrm{~g} / \mathrm{seedling}$. $75 \%$ of the seedlings germination with the salinity degree of $1.51 \mathrm{dS} / \mathrm{m}$ for RSL of $5 \mathrm{~cm}$ and DMAP of $0.005 \mathrm{~g} / \mathrm{seedling}$, whereas for RSL of $5 \mathrm{~cm}$ and DMAP of $0.010 \mathrm{~g} / \mathrm{seedling}$, the degree of salinity tolerated is $3.16 \mathrm{dS} / \mathrm{m}$. 
Nonetheless, for seedlings with RSL of $5 \mathrm{~cm}$ and DMAP of $0.015 \mathrm{~g} / \mathrm{seedling}$, the degree of salinity tolerated is $4.8 \mathrm{dS} / \mathrm{m}$.

These results evidenced the importance of mechanisms of salinity tolerance related to the retention of toxic ions in the roots. They also highlight the direct relation between the germination of millet seedlings and the preservation of photosynthetic tissues, since these are responsible for maintaining the metabolism and for the continuity of the development.

\section{Conclusions}

The beta regression model proved to be an appropriate option to analyse the millet seedling germination rate after 72 hours in function of salinity level, length of the root system and dry mass of the aerial part.

To each increment of one $\mathrm{dS} / \mathrm{m}$ in the level of salinity, it is expected $32 \%$ of decrease in the seedling germination, on average.

To each increment of one centimetre in the length of root system, an increase of approximately $23.37 \%$ in the germination of millet seedling is expected.

To each increase of 0.01 grams in the dry mass aerial part per seedling, it is expected a mean increase of $26.87 \%$ in the seedling germination.

LUCENA, L. R. R., SIMÕES, V. J. L. P., BEZERRA, C. W. F., IZIDRO, J. L. P. S., SOUZA, M. S., LEITE, M. L. M. V. Taxa de Germinação de plântula de Pennisetum glaucum em função do estresse salino, comprimento e biomassa da parte aérea e raiz. Rev. Bras. Biom., Lavras, v.37, n.4, p.481-492, 2019.

- RESUMO: O milheto é uma planta de ciclo anual com metabolismo C4 tolerante ao déficit hídrico e cultivado em locais com escassez de chuva. Objetivou-se avaliar a germinação de plântula do milheto em função do nível salino, crescimento e biomassa da parte aérea e do sistema radicular. $O$ experimento foi instalado no delineamento inteiramente casualisados, com quatro tratamentos e cinco repetições, sendo a unidade experimental representada por uma bandeja de 120 células contendo 24 sementes por tratamento. Os tratamentos foram constituídos pelas soluções de $\mathrm{NaCl}$ correspondentes a 2,337, 4,674 e 7,011 g/L, respectivamente para as condutividades elétricas (CE) 4,0; 8,0; 12,0 dS. $\mathrm{m}^{-1}$ e 0 dS. $\mathrm{m}^{-1}$ como testemunha. A cultivar de milheto utilizada foi a IPA Bulk $1 B F$. A média da taxa de germinação das plântulas em relação ao nível de salinidade testemunha foi superior a $90 \%$ e para o nível máximo de salinidade foi 0\%. O modelo proposto para explicar a taxa de germinação de plântula apresentou elevado poder de explicação $(90,96 \%)$ e baixa soma de quadrados de resíduos (0,26). A taxa de germinação das plântulas pode ser explicada pelo modelo de regressão beta levando em consideração o nível de salinidade, o comprimento do sistema radicular e a massa seca da parte aérea.

- PALAVRAS-CHAVE: Milheto, modelagem, mortalidade, regressão beta

\section{References}

AKAIKE, H. A new look at the statistical model identification. IEEE Transactions on Automatic Control, v.19, n.6, p.716-723, 1974. 
ALVES, F.A.L.; FERREIRA-SILVA, S.L.; SILVEIRA, J.A.G.; PEREIRA, V.L.A. Efeito do $\mathrm{Ca}^{2+}$ externo no conteúdo de $\mathrm{Na}^{+}$e $\mathrm{K}^{+}$em cajueiros expostos a salinidade. Revista Brasileira de Ciências Agrárias, v.6, n.4, p.602-608, 2011.

AQUINO, A.J.S.; LACERDA, C.F.; BEZERRA, M.A.; FILHO, E.G.; COSTA, R.N.T. Crescimento, partição de matéria seca e retenção de $\mathrm{Na}^{+}, \mathrm{K}^{+}$e $\mathrm{Cl}^{-}$em dois genótipos de sorgo irrigados com águas salinas. Revista Brasileira de Ciência do Solo, v.31, n.5, p.961971, 2007.

ARAUJO, E. B. G.; SÁ, F. V. S.; OLIVEIRA, F. A.; SOUTO, L. S.; PAIVA, E. P.; SILVA, M. K. N.; MESQUITA, E. F.; BRITO, M. E. B. Crescimento inicial e tolerância de cultivares de meloeiro à salinidade da água. Revista Ambiente \& Água, v.11, n.2, p.462-471, 2016.

ARAÚJO, S. A. C.; VASQUEZ, H. M.; CAMPOSTRINI, E.; NETTO, A. T.; DEMINICIS, B. B.; LIMA, E. S. Características fotossintéticas de genótipos de capimelefante anão (Pennisetum purpureum Schum.), em estresse hídrico. Acta Scientiarum. Animal Sciences, v.32, n.1, p.1-7, 2010.

CAVALCANTE, L. F.; CORDEIRO, J. C.; NASCIMENTO, J. A. M.; CAVALCANTE, I. H. L.; DIAS, T. J. Fontes e níveis da salinidade da água na formação de mudas de mamoeiro cv. sun rise solo. Semina: Ciências Agrárias, v.31, n.4, p.1281-1290, 2010.

CRIBARI-NETO, F.; ZEILEIS, A. Beta regression in R. Journal of Statistical Software, v.34, n.2, p.1-24, 2010.

DAN, H. A.; BARROSO, A. L. L.; PROCÓPIO, S. O.; DAN, L. G. M.; FINOTTI, T. R.; ASSIS, R. L. Seletividade do atrazine à cultura do milheto (Pennisetum glaucum). Planta Daninha, v.28, n.4, p.1117-1124, 2010.

EKLESTON, B. N. I.; MADSEN, L.; HAGAR, J. C.; TEMESGEN, H. Estimating riparian understory vegetation cover with beta regression and copula models. Forest Science, v.57, n.3, p.212-221, 2011.

FERRARI, S. L. P.; CRIBARI-NETO, F. Beta regression for modelling rates and proportions. Journal of Applied Statistics, v.31, n.7, p.799-815, 2004.

GHATAK, A.; CHATURVEDI, P.; NAGLER, M.; ROUSTAN, V.; LYON, D.; BACHMANN, G.; POSTL, W.; SCHROFL, A; DESAI, N.; VARSHNEY, R. K.; WECKWERTH, W. Comprehensive tissue-specific proteome analysis of drought stress responses in Pennisetum glaucum (L.) R. Br. (Pearl millet). Journal of Proteomics, v.143, n.30, p.122-135, 2016.

GOMES, K. R.; AMORIM, A. V.; FERREIRA, F. J.; FILHO, F. L. A.; LACERDA, C. F.; GOMES-FILHO, E. Respostas de crescimento e fisiologia do milho submetido a estresse salino com diferentes espaçamentos de cultivo. Revista Brasileira de Engenharia Agrícola e Ambiental, v.15, n.4, p.365-370, 2011.

HUSSAIN, K.; MAJEED, A.; NAWAZ, K.; NISAR, M. F.; KHAN, F.; AFGHAN, S.; ALI, K. Comparative study for salt stress among seed, root stock and direct regenerated violet (Viola odorata L.) seedlings in relation to growth, ion contents and enzyme activities. African Journal Biotechnology, v.9, n.14, p.2108-2117, 2010. 
HUSSAIN, K.; ASHRAF, M.; ASHRAF, M. Y. Relationship between growth and ion relation in pearl millet (Pennisetum glaucum (L.) R. Br.) at different growth stages under salt stress. African Journal of Plant Science, v.2, n.3, p.23-27, 2008.

KRISHNAMURTHY, L. R.; SERRAJ, R.; RAI, K. N.; HASH, C. T.; DAKHEEL, A. J. Identification of pearl millet [Pennisetum glaucum (L.) R. Br.] lines tolerant to soil salinity. Euphytica, v.158, n.1-2, p.179-188, 2007.

LEITE, M. L. M. V.; LUCENA, L. R. R.; SÁ JR., E. H.; CRUZ, M. G. Estimativa da área foliar em Urochloa mosambicensis por dimensões lineares. Revista Agropecuária Técnica, v.38, n.1, p.9-16, 2017.

LI, F.; ZHANG, L.; DAVIS, C. J. Modeling the joint distribution of tree diameters and heights by bivariate generalized beta distribution. Forest Science, v.48, n.1, p.47-58, 2002.

NOBRE, R. G.; LIMA, G. S.; GHEYI, H. R.; LOURENÇO, G. S.; SOARES, L. A. A. Emergência, Crescimento e produção da mamoneira sob estresse salino e adubação nitrogenada. Revista Ciência Agronômica, v.44, n.1, p.76-85, 2013.

R CORE TEAM. R: A Language and Environment for Statistical Computing. R Foundation for Statistical Computing, Vienna, Austria, 2018.

SANTOS, K. C.; MAGAlhãeS, A. L. R.; SIlVA, D. K. A.; ARAÚJO, G. G. L.; FAGUNDES, G. M.; YBARRA, N. G.; ABDALLA, A. L. Nutritional potential of forage species found in Brazilian Semiarid region. Livestock Science, v.195, p.118-124, 2017.

SCHWARZ, G. Estimating the dimension of a model. The annals of statistics, v.6, n.2, p.461-464, 1978.

SILVA, J. R. I.; SOUZA, R. M. S.; SANTOS, W. A.; ALMEIDA, A. Q.; SOUZA, E. S.; ANTONINO, A. C. D. Aplicação do método de Budyko para modelagem do balanço hídrico no semiárido brasileiro. Scientia Plena, v.13, n.10, p.109908, 2017.

SINGH, J.; REDDY, P. S.; REDDY, C. S.; REDDY, M. K. Molecular cloning and characterization of salt inducible dehydrin gene from the $\mathrm{C} 4$ plant Pennisetum glaucum. Plant Gene, v.4, p.55-63, 2015.

SOARES, M. M.; SANTOS JR., H. C.; SIMÕES, M. G.; PAZZIN, D.; SILVA, L. J. Estresse hídrico e salino em sementes de soja classificadas em diferentes tamanhos. Pesquisa Agropecuária Tropical, v.45, n.4, p.370-378, 2015.

ULLAH, A.; AHMAD, A.; KHALIQ, T.; AKHTAR, J. Recognizing production options for pearl millet in Pakistan under changing climate scenarios. Journal of Integrative Agriculture, v.16, n.4, p.762-773, 2017.

Received on 20.01.2019

Approved after revised on 07.11.2019 